\title{
Longitudinal Relations Between Parenting Stress and Young Children's Aggressive and Cooperative Behaviors: The Mediating Effect of Co-Parenting
}

\author{
Youngsook Han \\ Research Associate, Center for Children and Families Across Cultures, University of Missouri, Columbia, USA \\ 부모의 양육스트레스와 유아의 공격적·협동적 행동의 종단적 관계: \\ 부모공동양육의 매개효과 \\ 한영숙 \\ 미주리대학교 다문화 아동·가족센터 연구원
}

Objectives: This study examined the longitudinal relations between mothers' and fathers' parenting stress and young children's aggressive and cooperative behaviors via mothers' and fathers' coparenting behaviors.

Methods: The sample consisted of 1,692 mothers, fathers, and their young children ( $M$ age $=5$ years at T1; $51 \%$ boys) who participated in the Panel Study on Korean Children. Structural equation modeling was conducted to examine the relations among parenting stress, co-parenting, and young children's aggressive and cooperative behaviors.

Results: Mothers' and fathers' parenting stress were longitudinally associated with their own and their partners' positive and conflict-ridden co-parenting behaviors, which in turn predicted young children's aggressive and cooperative behaviors. Moreover, the positive and conflict-ridden coparenting behaviors of mothers in particular played mediating roles in the longitudinal links between mothers' and fathers' parenting stress and young children's aggressive and cooperative behaviors.

Conclusions: The present findings contributed to our understanding about the intervening mechanisms that account for how parenting stress is related to young children's aggressive and cooperative behaviors.

Keywords: parenting stress, co-parenting, aggressive behavior, cooperative behavior, young children

\section{Introduction}

그동안 많은 선행연구들을 통하여 부모의 양육스트레스가 유 아의 다양한 사회적 부적응을 예측하는 중요한 요인임이 나 타났다(Liu \& Wang, 2015a). 그러나 대부분의 선행연구들은 유아의 외현화 문제행동이나 우울과 같은 부정적인 측면의

Corresponding Author: Youngsook Han, Research Associate, Center for Children and Families Across Cultures, University of Missouri, 314 Gentry Hall, Columbia, USA

E-mail:yhm88@missouri.edu
발달에 미치는 횡단적 영향에 초점을 맞추어(Huth-Bocks \& Hughes, 2008), 부모의 양육스트레스가 유아의 협동적인 행 동과 같은 긍정적인 발달에도 종단적 영향을 미치는지에 대 해서는 간과한 측면이 있다. 또한 부모의 양육스트레스가 유 아의 긍정적 · 부정적인 발달에 어떤 방식으로 영향을 미치는 지에 대해서 연구될 필요가 있다. 선행연구들에 따르면 부모

(C)The Korean Association of Child Studies

This is an Open Access article distributed under the terms of the Creative Commons Attribution Non-Commercial License (http:// creativecommons.org/licenses/by-nc/4.0) which permits unrestricted noncommercial use, distribution, and reproduction in any medium, provided the original work is properly cited. 
가 양육스트레스를 높게 인지할수록 이들의 긍정적인 공동양 육행동은 저하되고, 부정적인 공동양육행동을 더 많이 보이 는 것으로 나타났다(Brote-Tinkew, Horowitz, \& Carrano, 2010; Richardson, Futris, Mallette, \& Campbell, 2018). 부모공동양육 은 부부가 부모로서 자녀들의 양육과 관련된 일을 그들의 배 우자와 함께 하는 활동을 의미하는 것으로(Feinberg, 2002), 부 모가 서로의 양육행동을 지지하고 협동하는 긍정적 유형의 부 모공동양육과 배우자의 양육행동 및 노력을 폄하하거나 갈등 을 일으키는 등의 부정적 유형의 부모공동양육으로 특징지어 진다(Margolin, Gordis, \& John, 2001). 특히 부모의 공동양육행 동은 유아기와 학령기 아동의 친사회적 · 공격적 행동을 예측 하는 요인으로 보고되고 있어(Scrimgeour, Blandon, Stifter, \& Buss, 2013; Teubert \& Pinquart, 2010), 부모의 공동양육이 양육 스트레스와 유아의 발달간의 관계를 매개할 것이라 추측해 볼 수 있다. 아울러 기존의 연구들은 유아의 긍정적 - 부정적 발 달을 이해함에 있어 어머니 역할에 비해 아버지 역할에 대하 여 상대적으로 주목하지 않았다. 이러한 선행연구들의 제한점 들을 보완하기 위하여 어머니와 아버지의 양육스트레스, 어 머니와 아버지의 공동양육 행동, 유아의 공격적 - 협동적 행동 간의 관계를 종단자료를 통하여 살펴볼 필요가 있다. 또한 어 머니와 아버지의 공동양육 행동이 어머니와 아버지의 양육스 트레스와 유아의 공격적 - 협동적 행동 간의 종단적 관계를 매 개하는지에 대한 연구가 필요하다.

Deater-Deckard (1998)가 제시한 이론적 모델에 따르면, 부 모의 양육스트레스는 역기능적인 부모-자녀 관계 및 양육행 동을 통해 자녀의 다양한 발달을 예측한다고 설명한다. 양육 스트레스는 부모됨의 책임감과 부담감으로 인한 부정적 감정 을 의미하는 것으로, 이러한 스트레스는 부모의 상호작용방식 이나 자녀의 적응과 같은 다른 영역으로 쉽게 전이되는 특성 이 있다(Deater-Deckard, 1998). 또한 양육스트레스는 자기 자 신과 자녀에 대한 부정적인 감정을 동반하는 경우가 많기 때 문에 부모가 자녀와 긍정적·기능적인 방식으로 상호작용하는 능력을 저하시킴으로써 자녀의 사회적 유능감에 영향을 주게 된다(Deater-Deckard, 1998, 2005). 이러한 이론적 모델은 부모 의 양육행동 및 자녀와의 관계에만 한정되는 것이 아니라, 부 모공동양육을 비롯한 다른 가족관계의 상호작용에 적용 가능 하다. Anthony 등(2005)은 부모됨으로부터 오는 심리적 스트 레스가 적대적·비반응적인 가족 간의 상호작용에 영향을 미 침으로써 자녀의 발달을 저해할 수 있음을 시사하였다. 이러 한 이론적 모델에 근거하여 부모의 양육스트레스는 다양한 유 형의 부모공동양육 행동에 영향을 미치고, 이는 이후 자녀의
발달을 예측할 수 있을 것으로 가정할 수 있다.

다음으로는 연구변인들에 대한 실증적 연구결과들을 살 펴보고자 한다. 선행연구들에서 부모의 양육스트레스는 유 아기와 학령기 아동의 다양한 사회적 적응을 예측하는 것으 로 나타났다(Anthony et al., 2005; Huth-Bocks \& Hughes, 2008; Owen, Thompson, \& Kaslow, 2006). 특히 유아기에 부모가 지 각하는 양육스트레스가 높게 나타나는 것으로 밝혀지고 있 어(Koeske \& Koeske, 1990), 유아기 자녀를 둔 부모의 양육스 트레스가 유아의 공격성과 협동성과 같은 긍정적 - 부정적 사회적 발달에 어떠한 영향을 미치는지에 대해 알아보는 것 이 중요하다. 이는 유아기와 아동기에 표출되는 공격성과 협 동성이 이후 지속적으로 청소년기의 또래관계를 포함한 다 양한 사회정서적 적응을 예측하는 주요한 요인이기 때문이 다(Campbell, Spieker, Burchinal, \& Poe, 2006; Kokko, Tremblay, Lacourse, Nagin, \& Vitaro, 2006). 선행연구들에 따르면, 양육 스트레스가 타인에게 신체적 손상을 입히거나 위협을 가하는 것과 같이 외현적으로 표출되는 행동인 외현적 공격성(Crick, Casas, \& Mosher, 1997)에 직접적인 영향을 미치는 것으로 보 고되고 있다(Y. A. Jang \& Lee, 2012; Jeon, 2015). 구체적으로는 어머니가 인지하는 자신의 양육스트레스가 높을수록 유아의 외현적 공격행동은 더 높아지는 경향이 있는 것으로 나타났다 (Y. A. Jang \& Lee, 2012; Jeon, 2015). 그러나 이 선행연구들에서 는 아버지의 양육스트레스가 포함되지 않아 어머니와 아버지 가 유아에게 미치는 영향의 차이를 밝힐 수 없었고, 종단적 자 료를 사용하지 않아 이러한 영향력의 지속성에 대해서도 알기 어려웠다. Liu와 Wang (2015a)의 연구에서는 어머니와 아버지 를 모두 포함시켜 연구한 결과, 어머니의 양육스트레스는 일 년 후 유아의 공격적 행동과 비행 행동을 직접적으로 예측한 반면 아버지의 양육스트레스는 유아의 공격적 행동에 직접적 인 관련이 없었다. 이러한 결과는 가족체계 이론적 관점에서 도 아동의 발달에 미치는 요인을 분석함에 있어 어머니와 아 버지를 동시에 연구하는 것이 중요하다는 것을 시사한다(Liu $\&$ Wang, 2015a).

부모의 양육스트레스는 유아의 공격성과 같은 부정적인 측 면의 발달뿐 아니라 친사회성이나 사회적 유능감과 같은 유아 의 긍정적인 측면의 발달에도 기여한다. 선행연구들에서 어머 니의 양육스트레스가 높을수록 어머니가 보고한 유아기 자녀 의 친사회성(H. E. Jang \& Kim, 2017) 및 사회적 유능감(Ryou, 2012)과 교실환경에서 교사가 평정한 유아의 친사회적 행동 (D. Y. Kim \& Jung, 2015)이 낮게 나타났다. 또 다른 연구에서 는 어머니의 양육으로 인한 일상적 스트레스와 2 년 후 유아의 
친사회적 행동 간의 부적 상관관계가 있는 것으로 나타났지 만 다른 매개변수들이 통합된 구조방정식 모델에서는 어머니 의 양육스트레스와 유아의 친사회적 행동 간의 유의한 관계가 나타나지 않았다(Gülseven et al., 2017). 이처럼 대부분의 선행 연구들에서는 아버지보다는 어머니의 양육스트레스가 유아 의 사회적 발달에 미치는 영향에 대해 주목하고 있다. 그러나 어머니와 아버지의 양육스트레스 수준은 차이를 보일 수 있고 (Deater-Deckard, 1998), 이는 유아의 발달에 각기 다른 영향을 줄 수 있음에도 불구하고 이에 대한 연구는 미흡한 실정이다.

위에서 살펴본 바와 같이 부모의 양육스트레스는 유아의 긍정적 - 부정적인 사회적 행동을 예측하며, 이러한 관계를 설 명함에 있어 부모-자녀간의 상호작용 및 행동양식을 이해하 는 것은 중요하다. 이는 선행연구들에서 부모의 양육스트레 스가 다양한 유형의 양육 행동에 부정적인 영향을 미친다고 보고하기 때문이다(Carapito, Ribeiro, Pereira, \& Roberto, 2018; Liu \& Wang, 2015b). 예를 들어, 어머니와 아버지가 인지하는 자신의 양육스트레스가 높을수록 자녀에게 신체적 체벌을 가 하거나(Liu \& Wang, 2015b), 일관되고 애정적인 태도로 양육 을 하지 않는 경향이 있었다(Carapito et al., 2018). 부부 자신의 문제가 부모-자녀 관계에 부정적으로 전이되는 이러한 현상 은 부모공동양육 관계에서도 찾아볼 수 있다. 선행연구에 따 르면, 위탁가정의 어머니들이 양육스트레스를 높게 인지할수 록 어머니가 평정한 긍정적인 공동양육 행동은 낮게 나타났 다(Richardsona et al., 2018). 또 다른 연구에서는 2,139명의 생 물학적 아버지만을 대상으로 그들의 양육스트레스와 공동양 육 행동 간의 관계를 파악한 결과, 어머니의 양육스트레스를 통제하고도 아버지의 양육스트레스가 높을수록 아버지는 비 협조적인 양육행동과 낮은 수준의 양육참여를 보였다(BroteTinkew et al., 2010). 특히 이러한 부정적인 결과는 저소득 가 정의 아버지에게서 보다 심화되는 것으로 보고되었다(BroteTinkew et al., 2010).

이러한 부모의 공동양육 행동은 유아의 다양한 사회적 적 응을 예측한다. 선행연구들에서 어머니가 비난적이고 갈등 적인 공동양육 행동을 많이 보일수록 만 4세 자녀의 공격적 인 행동 및 비행 문제행동은 높게 나타났고(McHale, Rao, \& Krasnow, 2000), 협조적이고 긍정적인 공동양육 행동이 많이 관찰될수록 일년 후 유아기 자녀의 공격적 - 반사회적 행동은 더 낮은 수준으로 부모의 의해 보고되었다(Schoppe, Frosch, \& Mangelsdorf, 2001). 부모의 공동양육 행동은 비단 유아의 부정 적 측면의 발달 뿐 아니라 협동적인 행동과 같은 친사회적 행 동에도 중요한 역할을 한다(Katz \& Low, 2004;. Scrimgeour et al., 2013). 협동적인 행동이란 다른 사람의 요구나 지시에 잘 따 르고, 집단 활동이나 또래들과의 상호작용에서 협력적인 모습 을 보이는 행동을 의미한다(Seo, 2004; Song \& Volling, 2015). 특히 연구자들은 부모가 자녀를 양육함에 있어 서로 돕고 온정 적인 태도로 참여하는 긍정적인 유형의 공동양육이 자녀가 가 족구성원에게 보이는 협동적인 행동에 중요한 영향을 미칠 것 으로 보았다(Song \& Volling, 2015). 구체적으로는 13개월에서 70 개월이 된 영유아들 중 동생이 태어난 지 한 달 된 아이들을 대상으로 동생의 기저귀를 가는 상황에서 이들의 협동적인 행 동을 관찰하였다(Song \& Volling, 2015). 그 결과, 배우자 서로 가 폄하하는 공동양육 행동을 많이 보이고 협동적인 공동양육 행동을 적게 보이는 부모들의 자녀들이 협동적인 행동을 적게 하는 것으로 관찰되었으며, 특히 진정 능력이 적은 기질의 자 녀들에게서 이러한 경향이 뚜렷했다(Song \& Volling, 2015).

선행연구들을 종합해보면, 부모의 양육스트레스는 자신의 공동양육 행동에 부정적인 영향을 미치고, 부정적인 공동양 육 행동은 다시 자녀의 사회적 적응을 예측한다. 그러나 부모 의 양육스트레스와 유아의 공격적 · 협동적 행동 간의 관계에 서 부모의 긍정적 - 갈등적 공동양육 행동이 매개효과가 있는 지에 대한 연구가 거의 없어 이에 대해 알아볼 필요가 있다. 또 한 어머니와 아버지를 동시에 포함시킨 연구가 드물어 어머 니와 아버지의 양육스트레스가 각각 자신과 상대방의 공동양 육 행동에 어떻게 예측하는지에 대해서 밝힐 필요가 있다. 또 한 선행연구들에서는 한 가지 유형의 부모공동양육 행동만을 측정하는 경향이 있어 보다 다양한 유형의 부모공동양육에 대 해 연구할 필요가 있다. 아울러 어머니와 아버지의 공동양육 행동이 유아기 자녀의 공격성 - 협동성과 같은 구체적인 사회 적 행동을 예측하는지 알아볼 필요가 있다. 따라서 본 연구에 서는 어머니와 아버지의 양육스트레스가 어머니와 아버지의 긍정적 · 갈등적 공동양육 행동과 어머니가 인식한 유아의 공 격적 행동과 어머니와 교사가 인식한 유아의 협동적인 행동에 종단적으로 어떠한 영향을 미치는지 살펴보고자 한다. 또한 어머니와 아버지의 긍정적 - 갈등적 공동양육 행동이 어머니 와 아버지의 양육스트레스와 유아의 공격적 · 협동적인 행동 간의 종단적 관계에서 매개효과가 있는지 검증하고자 한다.

\section{연구문제 1}

어머니와 아버지의 양육스트레스, 어머니와 아버지의 긍정 적 · 갈등적 공동양육 행동, 어머니가 인식한 유아의 공격적 행동과 어머니와 교사가 인식한 유아의 협동적인 행동 간의 직접적 관계가 있는가? 


\section{연구문제 2}

어머니와 아버지의 양육스트레스는 어머니와 아버지의 긍정 적 - 갈등적 공동양육 행동을 매개하여 간접적으로 어머니가 인식한 유아의 공격적 행동과 어머니와 교사가 인식한 유아 의 협동적인 행동을 예측하는가?

\section{Methods}

\section{연구대상}

본 연구의 대상은 한국아동패널(Panel Study on Korean Children) 6, 7차 년도에 참여한 1,692명의 유아들과 부모들이 다. 한국아동패널 연구진은 2008년(1차년도)부터 층화다단계 표본추출법을 사용하여 전국단위로(서울, 경기/인천, 충청/강 원, 경북, 경남, 전라) 데이터를 수집해 오고 있다. 1 차년도에 는 2,150 명의 유아들과 부모들이 참여하였고, 성별 비율은 남 아 1091명(51\%), 여아는 1059명(49\%)이다. 본 연구에서는 유 아들의 나이가 만 5세인 6차년도 자료(Time 1)와 유아들의 나 이가 만 6세인 7차년도 자료(Time 2)를 사용하여 분석하였다. 패널 6차년도 대비 7차년도의 표본 유지율은 $97.5 \%$ 로 높은 수 준인 것으로 나타났다.

부모의 교육 수준(Time 1)은 다음과 같다. 먼저 479명 (22.3\%)의 어머니와 435 명(20.2\%)의 아버지가 고등학교를 졸업했고, 439 명(20.4\%)의 어머니와 320 명(14.9\%)의 아버지 가 전문대(3년제 이하 기능대학)를 졸업하였다. 또한 630 명 (29.3\%)의 어머니와 701명(32.6\%)의 아버지가 대학교(4년제 이상)를 졸업하였고, 86 명(4\%)의 어머니와 172 명(8\%)의 아버 지가 대학원을 졸업하였다. 월평균 가구소득(Time 1)은 433만 원으로 나타났으며, 어머니와 아버지의 평균 연령(Time 1)은 각각 $36.1,38.6$ 세이었다.

\section{연구도구}

\section{양육스트레스}

어머니와 아버지는 각각 자신의 양육스트레스를 K. H. Kim과 Kang (1997)이 개발한 지필식 질문지를 이용하여 보고하였다. 총 11 문항으로 이루어진 이 도구는 5점 Likert 척도로서 전혀 그렇지 않다(1점)부터 매우 그렇다(5점)까지 평정한다. 점수가 높을수록 부모역할에 관한 스트레스와 부담이 크다는 것을 의미한다. 문
항의 예로는 "아이로부터 도망치고 싶을 때가 있다.", "아이가 정 서적으로 불안정한 모습을 보이면 내 탓인 것 같아 괴롭다.” 등 이 있다. 본 연구에서 산출한 내적합치도 계수 Cronbach's $\alpha$ 는 어 머니 응답과 아버지 응답 모두 .87 (Time 1)이었다.

\section{부모공동양육}

어머니와 아버지의 공동양육은 McHale (1997)의 도구를 토대 로 한국아동패널 연구진이 번역 및 예비조사를 실시 후 사용한 도구를 활용하여 측정하였다. 자신의 공동양육을 보고하는 지 필식 설문지로 총 16 문항으로 구성되어있다. 총 4 개의 하위 영 역(가족통합, 비난, 갈등, 훈육)으로 구성되어 있지만 긍정적인 공동양육을 의미하는 가족통합 척도의 7문항과 부정적인 공동 양육을 나타내는 갈등 척도의 2 문항이 사용되어 총 9 문항이 분 석에 포함되었다. 비난(어머니 응답의 Cronbach's $\alpha=.42$, 아버 지 응답의 Cronbach's $\alpha=.34$ )과 훈육(어머니 응답의 Cronbach's $\alpha=.15$, 아버지 응답의 Cronbach's $\alpha=.14$ ) 척도의 내적합치도 계수는 .7보다 낮아 본 연구에서 제외되었다(Cortina, 1993). 이 도구는 7점 Likert 척도로서 전혀 그렇지 않다(1점)부터 매우 그 렇다(7점)까지 평정한다. 가족통합 척도의 예로는 "나는 나와 배우자, 아이가 함께 있을 때 배우자가 아이가 다정하고 즐거운 놀이를 할 수 있도록 말이나 행동으로 도와준다.”, "나는 배우 자 없이 아이가 함께 있을 때 배우자가 없는 상황에서 배우자를 언급하거나 상황에 포함시킨다.” 등이 있다. 갈등 척도의 예로 는 "나는 나와 배우자, 아이가 함께 있을 때 배우자와 언쟁(말싸 움)을 한다.”, "배우자와 이야기를 할 때 약간 긴장된 분위기가 조성되거나 빈정거리며 말한다.” 등이 있다. 가족통합 척도의 점수가 높을수록 긍정적·협동적인 공동양육이 이루어지고 있 음을 뜻하고, 갈등 척도의 점수가 높을수록 다툼이 많고 비협 조적인 공동양육이 이루어지고 있음을 나타낸다. 따라서 본 연 구에서는 가족통합 척도를 사용하여 긍정적인 공동양육이 측 정되었고, 갈등 척도를 사용하여 갈등적인 공동양육이 측정되 었다. 본 연구에서 산출한 가족통합 척도(긍정적인 공동양육) 의 내적합치도 계수 Cronbach's $\alpha$ 는 어머니 응답이 .84 (Time 2), 아버지 응답이 89 (Time 2)이었다. 또한 갈등 척도(갈등적인 공 동양육)의 내적합치도 계수 Cronbach's $\alpha$ 는 어머니 응답이 .81 (Time 2), 아버지 응답이 .78 (Time 2)이었다.

\section{공격적인 행동}

유아의 공격적인 행동은 $\mathrm{Oh}$ 와 $\mathrm{Kim}$ (2009)의 유아행동평가척 
도(Child Behavior Checklist 1.5-5 [CBCL 1.5-5]) 매뉴얼 개정판 을 어머니의 응답을 통하여 측정하였다. 다양한 문제행동들을 평가하는 유아행동평가 척도에서 본 연구의 목적에 맞게 공격 적인 행동에 해당하는 공격행동 하위척도만을 사용하였으며, 공격적인 행동은 총 19 개의 문항으로 구성되어 있다. 이 도구 는 3점 Likert 척도로서 전혀 해당되지 않는다(0점)부터 자주 그런 일이 있거나 많이 그렇다(2점)까지 평정하였다. 점수가 높을수록 타인에게 신체적 공격을 하는 등의 위협을 가하는 행동을 많이 보이는 것으로 나타난다. 본 연구에서 산출한 내 적합치도 계수 Cronbach's $\alpha$ 는 87 (Time 2)이었다.

\section{협동적인 행동}

유아의 협동적인 행동은 Gresham과 Elliott (1990)의 도구를 Seo (2004)가 국내 유아들을 대상으로 타당화 조사를 실시한 한국판 취학 전 유아용 사회적 기술 척도 (Korean Version of the Social Skill Rating System for Preschool Level [K-SSRS])의 협력 성 하위척도를 사용하여 측정하였다. 한국아동패널에 사용된 유아의 협동적인 행동 데이터는 어머니와 육아지원기관의 담 임교사가 평정하였다. 어머니 평정의 유아의 협력적인 행동 총 6 문항과 교사 평정의 유아의 협력적인 행동 총 9문항이 분 석에 사용되었다. 이 도구는 3점 Likert 척도로서 전혀 아니다 (1점)에서 매우 자주 그렇다(3점)의 범위로 평정하도록 구성 되었다. 협력성 척도의 예로는 "자발적으로 가족구성원의 일 을 돕는다.", "게임이나 놀이를 할 때 자신의 순서를 지킨다."
등이 있다. 점수가 높을수록 부모/교사의 지시에 잘 따르고, 또래와 잘 지내며, 협력적인 집단 활동을 보이는 정도가 높음 을 의미한다. 본 연구에서 산출한 협력적인 행동 척도의 내적 합치도 계수 Cronbach's $\alpha$ 는 어머니 응답이 .82 (Time 2), 교사 응답이 .89 (Time 2)이었다.

\section{통제변인}

부모의 사회경제적 수준은 선행연구들에서 아동의 공격성 및 친사회성에 유의한 관계가 있다고 보고되고 있어(Piff, Kraus, Côté, Cheng, \& Keltner, 2010; Pinderhughes, Dodge, Bates, Pettit, \& Zelli, 2000), 본 연구의 통제변인으로 고려되었으나 본 연구모델에서 유의한 관계를 보인 어머니와 아버지의 교육 수준만이 통제변인으로 사용되었다. 어머니와 아버지의 교육 수준은 유아의 보호자(어머니가 99\%)가 보고하였다. 어머니 와 아버지의 교육수준은 7점 Likert 척도를 통해 무학(1점)에 서부터 대학원졸업(7점)까지 평정하도록 구성되었다. 본 연구 에서 어머니와 아버지의 교육수준은 부모의 교육수준을 나타 내는 잠재변수로 분석에 사용되었다.

\section{자료분석}

연구변인들의 일반적 경향을 알아보기 위하여 SPSS WIN 21.0 (IBM Co., Armonk, NY)을 사용하여 변인별로 평균과 표준편 차를 산출하였으며, 변인들 간의 관계를 살펴보기 위하여 상

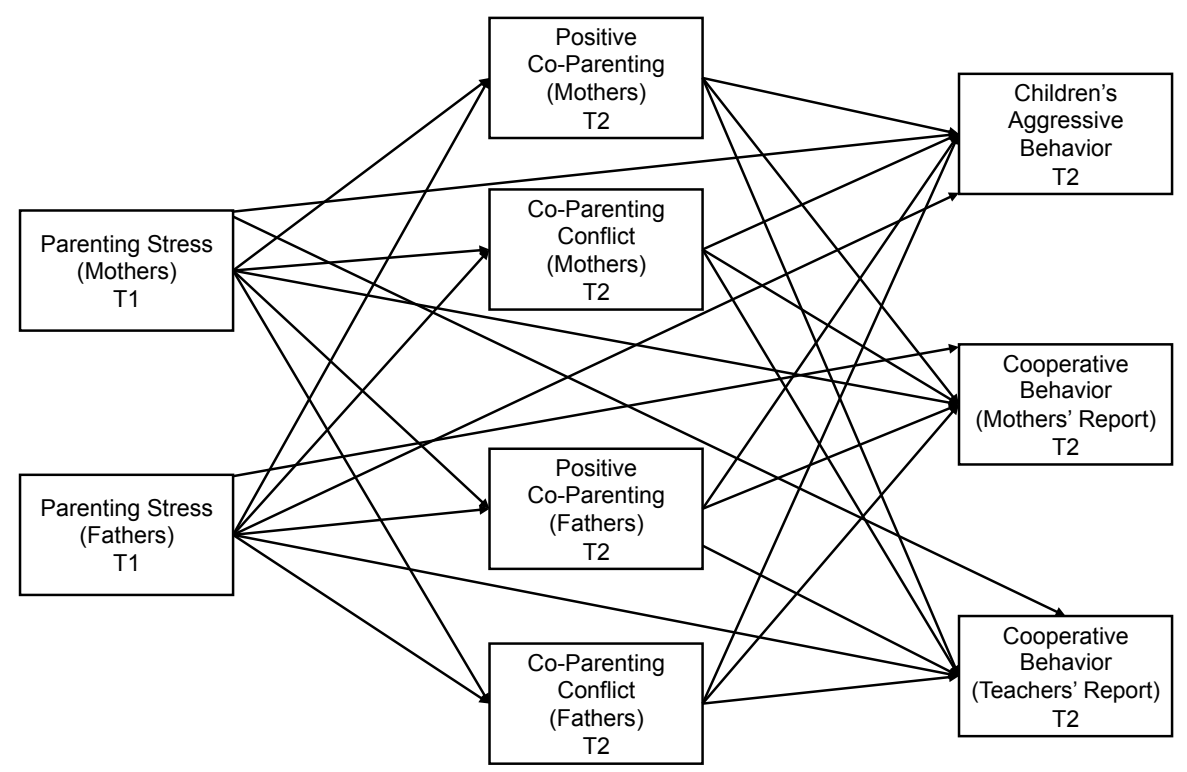

Figure 1. Research model. 
관분석을 실시하였다. 또한 본 연구에서 가정한 종단적 연구 모델을 살펴보기 위하여 STATA 14.2를 사용하여 구조방정식 (structural equation modeling)을 실시하였다(Figure 1). 구조방 정식을 실시할 때 결측치 처리를 위하여 완전정보 최대우도 법(full information maximum likelihood)을 분석에 사용하였고 (Acock, 2005), Time 1의 부모 교육수준을 통제하였다. 연구변 인들 간의 직접 효과와 간접 효과를 알아보았고, 간접 효과는 부트스트래핑 방법을 사용하여 분석하였다(Preacher \& Hayes, 2008).

\section{Results}

\section{연구변인들의 기술통계}

본 연구에서 측정한 변인들은 어머니와 아버지의 양육스트레 스, 어머니와 아버지의 긍정적 - 갈등적 공동양육행동, 유아의 공격적 - 협동적 행동이다. 각 변인들의 기술통계치를 알아본 결과는 Table 1에 제시하였다. 어머니와 아버지의 양육스트레 스의 문항평균 점수는 5점 척도에서 각각 $2.65,2.44$ 점으로, 만 5세 유아를 둔 어머니의 양육스트레스는 중간값보다 다소 높 은 편임을 보여주고, 아버지의 양육스트레스는 중간값에 가까 운 수준임을 보여준다. 어머니와 아버지의 긍정적인 공동양육 평균은 7점 척도에서 각각 $5.36,5.11$ 점으로 나타나 중간값보 다 높은 편이었고, 어머니와 아버지의 갈등적인 공동양육 평
균은 각각 $2.81,2.90$ 점으로 중간값보다 낮은 편이었다. 또한 유아의 공격적인 행동에 대한 문항평균 점수는 0-2점의 범위 에서 .24점으로 나타나 낮은 편이었고, 협동적인 행동에 대한 문항평균 점수는 3 점 척도에서 어머니 응답이 2.01점, 교사응 답이 2.65점으로 나타나 유아의 협동적인 행동 수준이 중간값 보다 높은 편임을 보여주었다.

\section{연구변인들의 상관관계}

어머니의 양육스트레스는 어머니의 갈등적인 공동양육 $(r=$ $.26, p<.001)$ 과 아버지의 갈등적인 공동양육 $(r=.22, p<.001)$ 과 정적 상관이 있었으며, 어머니의 긍정적인 공동양육 $(r=$ $-.32, p<.001)$ 과 아버지의 긍정적인 공동양육 $(r=-.19, p<$ .001)과는 부적상관을 보였다. 아버지의 양육스트레스 역시 어머니의 갈등적인 공동양육 $(r=.16, p<.001)$ 과 아버지의 갈 등적인 공동양육 $(r=.30, p<.001)$ 과 정적 상관이 있었으며, 어 머니의 긍정적인 공동양육 $(r=-.19, p<.001)$ 과 아버지의 긍정 적인 공동양육 $(r=-.30, p<.001)$ 과는 부적상관을 보였다. 어머 니의 긍정적인 공동양육은 어머니가 인식한 유아의 공격적인 행동 $(r=-.25, p<.001)$ 과 부적상관이 있었고, 유아의 협동적인 행동 $(r=.23, p<.001)$ 과는 정적상관이 있는 것으로 나타났다. 어머니의 갈등적인 공동양육은 어머니가 인식한 유아의 공격 적인 행동과 정적상관을 보였다 $(r=.21, p<.001)$. 이밖에도 연 구변인들 간의 유의한 상관관계가 있는 것으로 나타났고, 이 는 Table 1에 제시한 바와 같다.

Table 1

Means, Standard Deviations, and Correlations for the Main Study Variables

\begin{tabular}{|c|c|c|c|c|c|c|c|c|c|}
\hline & 1 & 2 & 3 & 4 & 5 & 6 & 7 & 8 & 9 \\
\hline 2. Fathers' parenting stress & $.43^{* * *}$ & - & & & & & & & \\
\hline 3. Mothers' positive co-parenting & $-.32^{* * *}$ & $-.19^{* * *}$ & 一 & & & & & & \\
\hline 4. Mothers' co-parenting conflict & $.26^{* * *}$ & $.16^{* * *}$ & $-.33^{* * *}$ & - & & & & & \\
\hline 5. Fathers' positive co-parenting & $-.19^{* * *}$ & $-.30^{* * *}$ & $.41^{* * *}$ & $-.21^{* * *}$ & - & & & & \\
\hline 7. Children's aggressive behavior & $.32^{* * *}$ & $.16^{* * *}$ & $-.25^{* * *}$ & $.21^{* * *}$ & $-.14^{* * *}$ & $.14^{* * *}$ & 一 & & \\
\hline 8. Children's cooperative behavior (MR) & $-.21^{* * *}$ & $-.14^{* * *}$ & $.23^{* * *}$ & $-.10^{* * *}$ & $.15^{* * *}$ & $-.12^{* * *}$ & $-.32^{* * *}$ & 一 & \\
\hline 9. Children's cooperative behavior (TR) & -.05 & $-.08^{* *}$ & $.07^{*}$ & -.05 & .05 & $-.08^{* *}$ & $-.21^{* * *}$ & $.13^{* * *}$ & - \\
\hline$M$ & 2.65 & 2.44 & 5.36 & 2.81 & 5.11 & 2.90 & .24 & 2.01 & 2.65 \\
\hline
\end{tabular}

Note. $\mathrm{MR}=$ mothers' report; $\mathrm{TR}=$ teachers' report.

${ }^{*} p<.05 .{ }^{* *} p<.01{ }^{* * *} p<.001$. 


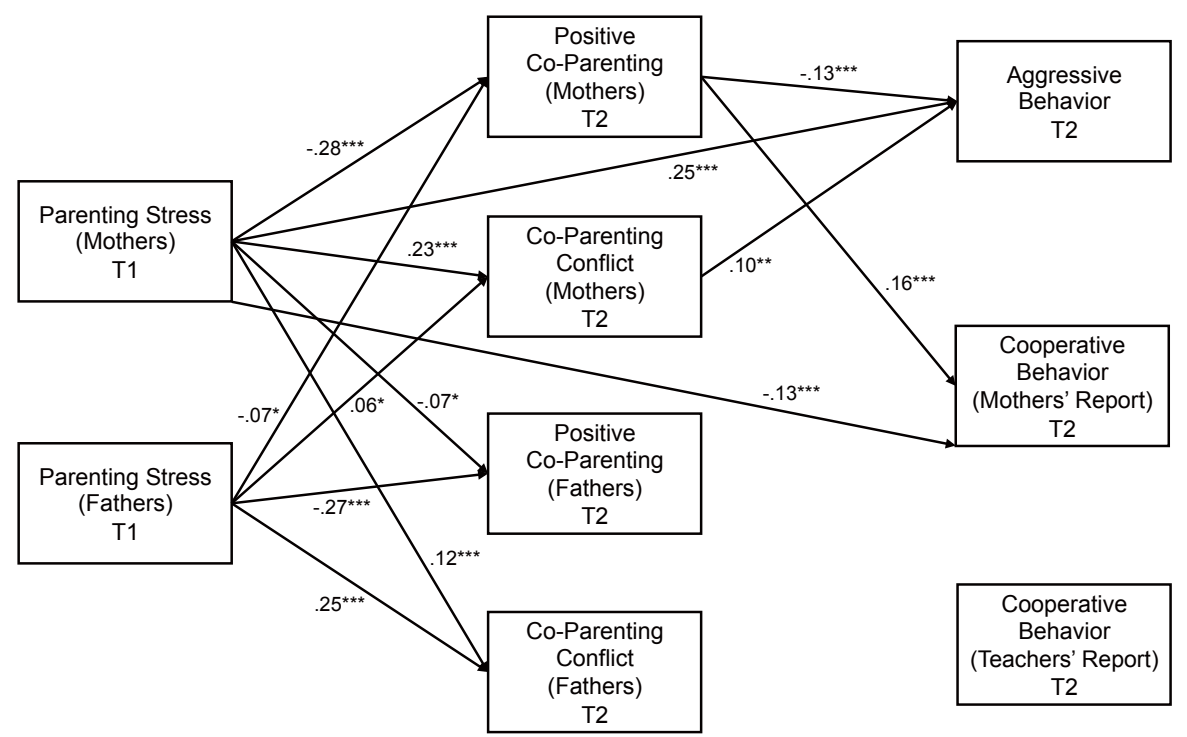

Figure 2. Longitudinal relations among parenting stress, co-parenting, and young children's aggressive and cooperative behaviors.

${ }^{*} p<.05 .{ }^{* *} p<.01 .{ }^{* * *} p<.001$.

\section{연구변인들에 대한 주요 분석}

변인들 간의 종단적 관계를 살펴보았고, 그 결과는 Figure 2 에 제시하였다. 모델 적합도는 $\chi^{2}(10)=93.49, p<.05 ; \chi^{2} / d f=$ 9.35, RMSEA $(90 \% \mathrm{CI})=.07(.06, .08), \mathrm{CFI}=.97$ 로 나타나 적 합도가 잘 충족되었다(Hu \& Bentler, 1999; Schermelleh-Engel, Moosbrugger, \& Müller, 2003). 먼저, 연구변인들 간의 직접적 인 관계가 있는지 살펴보았다. 그 결과, 어머니의 양육스트레 스는 일년 후 어머니가 인식한 유아의 공격적인 행동 $(\beta=.25$, $S E=.03, p<.001)$ 과 협동적인 행동 $(\beta=-.13, S E=.03, p<.001)$ 과 직접적인 관계가 있었고, 교사가 인식한 유아의 협동적인 행동은 예측하지 않는 것으로 나타났다. 반면, 아버지의 양육 스트레스는 일년 후 유아의 공격적 또는 협동적 행동과 직접 적인 관계가 없는 것으로 나타났다. 따라서 어머니의 양육스 트레스가 아버지의 양육스트레스보다 유아의 사회적 행동을 예측하는데 있어 더 주요한 요인임을 알 수 있다.

다음으로는 부모의 양육스트레스와 공동양육간의 관계를 알아보았다. Time 1 의 어머니 양육스트레스는 Time 2 의 어머 니 자신의 긍정적인 공동양육 행동 $(\beta=-.28, S E=.03, p<.001)$ 과 갈등적인 공동양육 행동 $(\beta=.23, S E=.03, p<.001)$ 에 직접 적인 관계가 있었고, 아버지의 긍정적인 공동양육 행동 $(\beta=$ -.07, $S E=.03, p<.05)$ 과 갈등적인 공동양육 행동 $(\beta=.12, S E=$ $.03, p<.001)$ 에도 직접적인 관계가 있었다. 또한 Time 1 의 아 버지 양육스트레스는 Time 2의 아버지 자신의 긍정적인 공동
양육 행동 $(\beta=-.27, S E=.03, p<.001)$ 과 갈등적인 공동양육 행 동 $(\beta=.25, S E=.03, p<.001)$ 에 직접적인 관계가 있었고, 어머 니의 긍정적인 공동양육 행동 $(\beta=-.07, S E=.03, p<.05)$ 과 갈 등적인 공동양육 행동 $(\beta=.06, S E=.03, p<.05)$ 에도 직접적인 관계가 있었다.

또한 어머니와 아버지의 긍정적 - 갈등적 공동양육(Time 2) 과 유아의 공격적·협동적 행동(Time 2)간의 직접적 관계를 살 펴보았다. 어머니의 긍정적인 공동양육 행동은 어머니가 인식 한 유아의 공격적인 행동 $(\beta=-.13, S E=.03, p<.001)$ 과 협동적 인 행동 $(\beta=.16, S E=.03, p<.001)$ 을 직접적으로 예측하였다. 어머니의 갈등적인 공동양육 행동은 어머니가 인식한 유아의 공격적인 행동 $(\beta=.10, S E=.03, p<.01)$ 과 직접적인 관계가 있 었고, 어머니와 교사가 인식한 유아의 협동적인 행동과는 직 접적인 관계가 없는 것으로 나타났다. 아버지의 긍정적·갈등 적인 공동양육 행동은 유아의 공격적·협동적인 행동과 직접 적인 관계가 없는 것으로 나타났다.

종합하면, 어머니의 양육스트레스는 일년 후 유아의 공격 적-협동적 행동과 직접적인 관계가 있었다. 또한 어머니와 아 버지의 양육스트레스는 각각 일년 후 자신과 배우자의 공동양 육 행동에 직접적인 영향을 미쳤고, 어머니의 긍정적인 공동 양육 행동은 유아의 공격적·협동적 행동을, 어머니의 갈등적 인 공동양육 행동은 유아의 협동적인 행동을 예측하는 것으로 나타났다. 따라서 본 연구결과는 어머니와 아버지의 양육스트 레스와 유아의 이후 사회적 행동 간의 관계에서 어머니의 긍 
정적 - 갈등적 공동양육 행동이 중요함을 알 수 있었다.

이러한 결과를 토대로 부모의 양육스트레스(Time 1)가 긍 정적 - 갈등적 공동양육 행동(Time 2)을 매개하여 유아의 공 격적 · 협동적 행동(Time 2)에 간접적인 영향을 미치는지 알 아보았다. 그 결과, 어머니의 양육스트레스(Time 1)는 어머니 의 긍정적인 공동양육 행동(Time 2)을 매개하여 Time 2의 어 머니가 인식하는 유아의 공격적인 행동(CIs = .26 to $.29, p<$ $.05)$ 과 협동적인 행동(CIs = -.04 to -.02, $p<.05)$ 을 예측하는 것으로 나타났다. 어머니의 갈등적인 공동양육 행동(Time 2) 역시 어머니의 양육스트레스(Time 1)와 유아의 공격적 행동 (Time 2)의 관계에서 매개효과가 있는 것으로 나타났다(CIs = .14 to $.19, p<.05$ ). 아버지의 양육스트레스(Time 1) 역시 어머 니의 긍정적인 공동양육 행동 (Time 2)을 매개하여 Time 2의 어머니가 인식하는 유아의 공격적인 행동(CIs = .06 to $.09, p$ $<.05)$ 과 협동적인 행동(CIs = -.02 to -.01, p <.05)을 예측하였 다. 마지막으로, 아버지의 양육스트레스(Time 1)는 어머니의 공동양육 갈등(Time 2)을 매개하여 어머니가 인식하는 유아 의 공격적인 행동(Time 2)에 영향을 주었다(CIs = .03 to .04, $p<$ .05). 그러나 어머니와 아버지의 공동양육행동(Time 2)은 어머 니와 아버지의 양육스트레스(Time 1)와 교사가 인식한 유아의 협동적인 행동(Time 2)을 매개하지 않는 것으로 나타났다. 종 합하면, 어머니의 긍정적 - 갈등적 공동양육 행동은 어머니와 아버지의 양육스트레스와 어머니가 인식한 유아의 공격적 · 협동적인 행동 간의 관계에서 매개효과가 있는 것으로 나타났 다.

\section{Discussion}

본 연구에서는 어머니와 아버지의 양육스트레스, 어머니와 아 버지의 공동양육, 유아의 공격적 · 협동적인 행동 간의 직접적 관계가 있는지 알아보았다. 또한 양육스트레스와 유아의 사회 적 발달간의 관계에서 어머니와 아버지의 공동양육 행동이 매 개적 효과가 있는지 검증하였다. 본 연구결과들에 대하여 논 의하고자한다.

첫째, 어머니의 양육스트레스는 일년 후 어머니가 보고한 자녀의 공격적 · 협동적인 행동과 직접적인 관계가 있었다. 이 는 어머니의 양육스트레스가 높을수록 유아기 자녀의 공격적 인 행동과 협동성을 포함한 친사회적 행동이 더 많이 나타난 다는 선행연구들의 결과와 일치한다(H. E. Jang \& Kim, 2017; Y. A. Jang \& Lee, 2012; Jeon, 2015; Gülseven et al., 2017). 연구
자들은 부모 자신과 아동이 양육스트레스로 인해 부정적 정서 를 빈번하게 경험한다고 보았다(Deater-Deckard, 1998, 2005). 따라서 어머니가 양육스트레스를 받을수록 가정 내에서 자녀 에게 표출하는 화, 분노, 우울과 같은 부정적 감정들이 자녀에 게 직접적인 영향을 미침으로써 자녀의 사회적 유능성을 감소 시키는 것으로 보인다. 한편, 아버지의 양육스트레스는 어머 니의 양육스트레스와 다르게 자녀의 공격적 · 협동적인 행동 을 예측하지 않았다. 대부분의 선행연구들에서 아버지를 포함 시키지 않아 비교하기 어렵지만, Liu와 Wang (2015a)의 연구 에서도 아버지의 양육스트레스는 일년 후 유아의 공격적인 행 동에 직접적인 영향을 미치지 않았다. 연구자들은 보편적으 로 가정 내에서 자녀양육에 있어 주도적 역할을 맡고 있는 어 머니들과 다르게 아버지는 기질과 같은 자녀의 특성이나 다른 요인으로 인해 양육참여정도나 양육행동이 달라지는 경향이 있다고 보았다(McBride, Schoppe, \& Rane, 2002). 따라서 아버 지가 인지하는 양육스트레스와 동반되는 부정적 감정의 정도 는 주 양육자인 어머니와 다를 수 있으며 상대적으로 아버지 의 양육스트레스가 자녀에게 직접적인 영향을 덜 미칠 가능성 이 있다. 또한 아버지의 양육스트레스와 유아의 공격적 · 협동 적 행동 간의 유의한 상관관계가 매개변인을 포함한 연구모형 에서는 다른 변인들의 관계를 함께 설명함으로써 유의하지 않 은 것으로 나타났을 가능성이 있다. 따라서 추후 후속연구들 을 통하여 아버지의 양육스트레스와 유아의 공격적 · 협동적 행동 간의 관계에 대하여 지속적으로 살펴볼 필요가 있다.

둘째, 어머니와 아버지의 양육스트레스는 일년 후 자신과 배우자의 긍정적 · 갈등적 공동양육 행동을 예측하였다. 이 는 부모의 양육스트레스가 높을수록 부정적인 양육행동은 증 가하고 긍정적인 공동양육 행동은 감소하는 경향이 있었다고 보고하는 선행연구들의 결과와 일치한다(Brote-Tinkew et al., 2010; Richardsona et al., 2016). 연구자들은 특히 부모됨으로 인한 부담감으로부터 오는 심리적 반응이나 부정적 정서가 자 녀와의 상호작용 및 관계에 쉽게 전이된다고 보았다(DeaterDeckard, 1998). 본 연구결과를 통하여 어머니 뿐 아니라 아버 지의 양육스트레스가 이후 어머니와 아버지의 공동양육 행동 에 중요한 영향을 미친다는 것을 파악하였다. 예를 들어, 어머 니 또는 아버지가 배우자와 함께 자녀를 양육함에 있어 많은 갈등을 빚고 비협조적인 태도를 보일 때 어머니 또는 아버지 자신의 양육스트레스가 감소될 수 있도록 중재하는 것 뿐 아 니라 배우자의 양육스트레스를 함께 감소시킬 수 있도록 하는 것이 보다 효과적인 중재방안이라 할 수 있다. 본 연구는 기존 의 어머니만을 포함시켜 연구했던 선행연구들과 달리 어머니 
와 아버지 각각의 양육스트레스와 세부적인 공동양육 행동 간 의 종단적 관계를 알아봄으로써 연구변인들에 대한 이해를 높 혔다.

셋째, 어머니의 긍정적인 공동양육 행동은 어머니가 인식 한 유아의 공격적·협동적인 행동을 직접적으로 예측하였고, 갈등적인 공동양육 행동은 어머니가 인식한 유아의 공격적인 행동과 직접적인 관계가 있었다. 이는 어머니의 공동양육 행 동이 자녀의 공격적인 행동과 같은 외현화 문제와 관련이 있 다고 밝힌 선행연구들의 결과와 일치한다(McHale et al., 2000; Schoppe et al., 2001). 또 다른 연구들에서는 어머니와 아버지 의 세부적인 공동양육 행동을 살펴보기보다 부모의 공동양육 행동이 자녀의 협동성과 같은 친사회적 행동을 예측하는지 살펴보았다(Katz \& Low, 2004;. Scrimgeour et al., 2013; Song \& Volling, 2015). 예를 들어, 부모가 협조적이고 온정적인 방식 으로 공동양육을 하는 것으로 관찰될 때 자녀는 협동적인 행 동을 더 많이 하는 것으로 나타났다(Song \& Volling, 2015). 어 머니의 공동양육 행동이 자녀의 공격적인 행동 뿐 아니라 협 동적인 행동에 영향을 미치는 것으로 나타난 본 연구결과는 선행연구들과 상당 부분 일치한다고 볼 수 있다. 사회학습이 론에 따르면, 아동은 다른 사람의 행동을 관찰하며 모델링의 과정을 통해 학습한다고 보았다(Bandura, 1977). 대부분의 시 간을 가정 내에서 부모와 함께 생활하는 유아기 자녀들은 부 모의 행동과 상호작용방식에 가장 많이 노출될 것이다. 부모 의 공동양육 과정에서 자녀는 부모와의 온정적이고 협동적인 상호작용을 통해 어떻게 타인을 돕고, 타인의 요구에 순응하 며, 협동하여 일을 하는지를 자연스럽게 학습하게 된다. 반면 에 갈등이 빈번한 환경에서 부모의 공격적인 행동을 자주 관 찰하게 되는 아동은 그러한 행동을 내재화함으로써 타인에게 부모와 비슷한 유형의 행동양식을 표출할 것이라 추측해 볼 수 있다.

그러나 아버지의 긍정적 또는 갈등적 공동양육 행동은 자 녀의 그 어떠한 사회적 행동도 예측하지 않았다. 선행연구들 에서는 연구자의 관찰에 의해 부모의 공동양육을 함께 측정 하였기 때문에(Katz \& Low, 2004;. Scrimgeour et al., 2013; Song \& Volling, 2015) 본 연구에서 어머니와 아버지가 자신의 공동 양육 행동을 스스로 평정하는 방식과는 차이가 있어 아버지의 공동양육 행동과 자녀의 사회적 발달간의 유의한 관계가 나타 나지 않았을 가능성을 배제할 수 없다. 연구자 관찰로 부모공 동양육 행동을 평정했다 하더라도 선행연구들에서 어머니와 아버지의 공동양육 행동을 세분화하여 측정했다면 다른 결과 가 나왔을 수 있다. 또한 아버지의 긍정적·갈등적 공동양육 행
동이 유아의 공격적·협동적 행동에 미치는 상대적 영향력이 매개변수 및 다른 변수들을 포함한 전체 연구모델에서 약화되 었을 가능성이 있다.

한편, 위 연구결과들에서 부모공동양육 또는 양육스트레 스는 교사가 인식한 유아의 협동적인 행동과 직접적인 관계 가 없는 것으로 나타났다. 그러나 유의한 관계를 보고했던 대 부분의 선행연구들에서는 부모가 응답한 친사회적 발달을 측 정하거나(Carapito et al., 2018; H. E. Jang \& Kim, 2017; Jeon, 2015; Ryou, 2012; Scrimgeour et al., 2013) 연구자의 관찰을 통 하여 유아의 협동적인 행동을 평가하였다(Katz \& Low, 2004; Song \& Volling, 2015). D. Y. Kim과 Jung (2015)의 연구에서는 상관관계분석을 통해 어머니의 양육스트레스와 교사가 평정 한 유아의 친사회성간의 유의한 관계를 밝혀냈다. 그러나 이 는 본 연구나 다른 선행연구들에서 사용한 구조방정식과는 방 법론의 차이가 있다. 본 연구에서는 특히 다른 변수들을 포함 하여 분석한 구조방정식에 의거한 연구모델이기 때문에 다른 변수들의 설명력을 고려해야한다. 앞서 제시한 본 연구의 상 관분석에서도 교사가 인식한 유아의 협동적인 행동은 아버지 의 양육스트레스와 갈등적인 공동양육과 부적상관을 보였고, 어머니의 긍정적인 공동양육과는 정적상관을 나타냈다. 따라 서 구조방정식을 통해 본 연구모델에서는 다른 변수들을 함께 설명되면서 교사가 인식한 유아의 협동적인 행동과 다른 연구 변인들 간의 유의한 관계가 사라졌을 수 있다. 또한 교사는 교 실환경에 제한하여 유아의 협동적인 행동을 관찰하고 평정하 지만 어머니는 주로 가정환경 내에서 살펴 본 유아의 사회적 발달을 측정했을 것이다. 본 연구는 가족의 내적 환경과 가족 상호작용에 초점을 둔 연구인만큼 어머니가 인식한 유아의 사 회적 행동이 양육스트레스와 공동양육행동과 보다 밀접한 관 계를 보였을 가능성이 있다. 선행연구자들은 한명의 응답자에 의한 정보에 의존하기보다 다양한 보고자들에 의한 결과를 비 교함으로써 보다 객관적인 정보를 파악할 필요가 있다고 주장 하고 있다(Park \& Park, 2017). 따라서 본 연구는 어머니, 아버 지, 교사를 포함하여 보고자들 간의 결과를 비교할 수 있었고, 이에 대한 보다 풍성한 정보를 제공함으로써 연구변인들에 대 한 이해를 도왔다고 볼 수 있다.

넷째, 어머니와 아버지의 양육스트레스는 어머니의 긍정적 인 공동양육 행동을 매개하여 일년 후 어머니가 인식하는 유 아의 공격적·협동적 행동을 예측하는 것으로 나타났다. 어머 니의 갈등적인 공동양육 행동 역시 어머니와 아버지의 양육스 트레스와 유아의 공격적 행동의 종단적 관계를 매개하였다. 이러한 결과는 Deater-Deckard (1998)가 제시한 이론적 모델과 
일치한다. Deater-Deckard (1998)는 부모의 양육스트레스가 부 모-자녀 관계 및 양육행동을 통하여 자녀의 다양한 발달을 예 측한다고 보았다. 특히 양육스트레스와 동반되는 부정적 정서 와 심리적 반응은 자녀와의 애정적이고 지지적인 상호작용을 방해함으로써 자녀의 사회적 발달을 저하시키는 결과를 초래 하게 된다(Deater-Deckard, 1998, 2005). 또한 주목할만한 점은 아버지의 공동양육 행동과 다르게 어머니의 긍정적 - 갈등적 공동양육 행동이 어머니와 아버지의 양육스트레스와 유아의 사회적 행동 간의 관계에서 중요한 역할을 하는 것으로 나타 났다는 점이다. 이는 유아의 공격성 문제를 해결하고 협동성 을 증진시키기 위해서는 어머니가 배우자와 자녀를 함께 양육 함에 있어 보이게 되는 자신의 긍정적인 행동을 보다 강화하 고, 부정적인 행동들은 표출되지 않도록 중재할 필요가 있다 는 것을 시사한다. 예를 들어, 어머니는 자녀 앞에서 배우자의 양육행동에 대하여 칭찬하고 인정하며, 협조적인 태도로 공동 양육을 할 필요가 있다. 또한 어머니와 아버지의 양육스트레 스 모두 어머니의 공동양육 행동과 유아의 사회적 행동에 영 향을 미치는 중요한 예측변수였다는 점도 중요한 결과라고 할 수 있다. 기존의 어머니의 양육스트레스 및 양육관련 변인들 에만 주목해왔던 선행연구들과 달리 본 연구는 어머니뿐만 아 니라 아버지가 가족 간 상호작용과 자녀의 발달을 예측한다는 것을 밝혔다. 과거와 달리 자녀를 양육함에 있어 부부 모두에 게 책임이 있다는 인식이 확대됨에 따라 어머니만큼이나 아버 지가 경험하는 스트레스도 비슷하게 높은 수준일 것임을 예측 해볼 때(Jeon, 2015), 본 연구결과는 아버지의 양육스트레스를 어머니의 양육스트레스와 함께 연구하고 비교함으로써 아동 의 사회적 유능성을 증진하는데 보다 효과적인 중재방안의 기 초를 제공하였다.

마지막으로 본 연구의 제한점과 후속 연구를 위한 제언은 다음과 같다. 먼저 본 연구는 2 개년도의 종단적 자료만을 활용 하여 연구변인들 간의 관계를 파악하였다. 부모의 양육스트레 스와 일년 후 공동양육 행동 및 자녀의 사회적 발달을 측정하 였는데, 후속 연구에서는 이년 후 유아의 사회적 발달을 측정 하여 3개년도의 종단적 자료를 바탕으로 연구함으로써 연구 변인들에 대한 이해를 도울 수 있을 것이다. 아울러 본 연구는 종단설계를 바탕으로 한 연구이지만 연구변인들 간의 인과관 계를 분명하게 규정할 수는 없다. 예컨대 후속 연구에서는 실 험연구를 통하여 연구변인들 간의 확실한 인과관계를 살펴볼 필요가 있다. 셋째, 본 연구의 사용된 부모 질문지는 부모 스스 로 자신의 양육스트레스와 공동양육 행동을 측정하는 것으로 써 보다 다양한 관점과 환경에서 평가될 수 있는 객관적 도구
와 함께 다양한 방법론적 접근이 필요하다. 특히 공동양육 행 동의 경우 배우자와 함께 하는 양육활동인 만큼 배우자가 인 식하는 상대방의 공동양육 행동이 보다 나은 평가방법일 수 있다(Margolin et al., 2001). 또한 연구자들이 부모와 자녀의 상 호작용을 관찰함으로써 세부적인 부모공동양육 행동과 자녀 의 공격적 · 협동적인 행동을 측정할 수 있다.

이러한 제한점에도 불구하고 본 연구의 장점 및 시사점은 다 음과 같다. 첫째, 횡단적 자료를 바탕으로 연구변인들 간의 관 계를 살펴 본 대부분의 선행연구들과 다르게 본 연구는 전국지 역의 유아들과 부모들을 대상으로 추적 조사한 한국아동패널 데이터를 통하여 양육스트레스가 종단적으로 부모의 공동양육 행동과 유아의 공격적 · 협동적인 행동을 예측한다는 것을 밝혔 다. 본 연구결과는 양육스트레스가 높은 가정을 대상으로 하는 조기 중재 및 예방을 위한 대책이 유아의 건강한 사회적 발달을 위해 무엇보다 중요함을 시사한다. 둘째, 본 연구는 어머니의 긍정적·갈등적 공동양육 행동이 부모의 양육스트레스와 유아 기 자녀의 사회적 발달간의 관계를 설명하는 중요한 메커니즘 임을 밝혀 구체적이고 효과적인 중재방안을 마련하는데 기초 를 제공하였다. 셋째, 본 연구는 어머니와 아버지의 각각 양육 스트레스와 세부적인 공동양육 행동을 측정하고 비교함으로써 연구변인들에 대한 심도있는 이해를 높이고자 하였다. 특히 기 존의 연구들은 어머니의 양육관련 변인들만을 주목하거나 연 구의 편의성으로 인하여 어머니만을 포함시켜 연구하는 경향 이 있어 아버지의 양육스트레스와 공동양육 행동이 어떻게 자 녀의 공격성과 협동성을 예측하는지에 대한 이해가 부족하였 다. 따라서 본 연구결과를 통하여 아버지의 양육스트레스 역시 공동양육 행동을 통해 자녀의 사회적 발달을 예측하는 주요한 요인임을 시사하였다. 넷째, 본 연구는 부모의 공동양육 행동과 자녀의 발달을 측정함에 있어 긍정적인 측면과 부정적인 측면 모두를 고려하여 연구를 설계하였다. 이를 통해 부모의 양육스 트레스가 부정적인 측면의 공동양육 행동과 자녀 발달에만 기 여하는 것이 아니라 긍정적인 발달을 저해할 수 있다는 것을 보 여주었다. 종합하면, 본 연구는 유아의 공격적인 행동을 줄이기 위해서는 어머니의 긍정적인 공동양육 행동을 증진시키고 갈 등적인 공동양육 행동은 감소시킬 수 있도록 중재하는 것이 무 엇보다 중요하다는 것을 시사한다. 또한 유아의 협동적인 행동 을 강화시키기 위해서는 어머니의 긍정적인 공동양육에 초점을 두고 향상시키기 위해 노력하는 것이 중요함을 알 수 있다. 아 울러 어머니의 양육스트레스와 못지않게 아버지의 양육스트레 스를 감소시키는 것이 유아의 사회적 발달을 효과적으로 향상 시키는데 있어 중요한 방안임을 시사한다. 


\section{Notes}

This article was presented at the 2019 Biennial Meeting of the Society for Research in Child Development, Baltimore, MD.

\section{Conflict of Interest}

No potential conflict of interest relevant to this article was reported.

\section{References}

\section{In English}

Acock, A. C. (2005). Working with missing values. Journal of Marriage and Family, 67(4), 1012-1028. doi:10.1111/j.17413737.2005.00191.x

Anthony, L. G., Anthony, B. J., Glanville, D. N., Naiman, D. Q., Waanders, C., \& Shaffer, S. (2005). The relationships between parenting stress, parenting behavior and preschoolers' social competence and behaviour problems in the classroom. Infant and Child Development, 14(2), 133-154. doi:10.1002/icd.385

Bandura, A. (1977). Social learning theory. New York: Prentice Hall.

Bronte-Tinkew, J., Horowitz, A., \& Carrano, J. (2010). Aggravation and stress in parenting: Associations with coparenting and father engagement among resident fathers. Journal of Family Issues, 31(4), 525-555. doi:10.1177/0192513X09340147

Campbell, S. B., Spieker, S., Burchinal, M., \& Poe, M. D. (2006). Trajectories of aggression from toddlerhood to age 9 predict academic and social functioning through age 12 . The Journal of Psychology and Psychiatry, 47(8), 791-800. doi:10.1111/j.1469-7610.2006.01636.x

Carapito, E., Ribeiro, M. T., Pereira, A. I., \& Roberto, M. S. (2018). Parenting stress and preschoolers' socio-emotional adjustment: The mediating role of parenting styles in parent-child dyads. Journal of Family Studies, 1-17. doi:10. 1080/13229400.2018.1442737

Cortina, J. M. (1993). What is coefficient alpha? An examination of theory and applications. Journal of Applied Psychology, 78(1), 98-104. doi:10.1037/0021-9010.78.1.98

Crick, N. R., Casas, J. F., \& Mosher, M. (1997). Relational and overt aggression in preschool. Developmental Psychology, 33(4), 579-588. doi:10.1037/0012-1649.33.4.579

Deater-Deckard, K. (1998). Parenting stress and child adjustment: Some old hypotheses and new questions. Clinical Psychologist:
Science and Practice, 5(3), 314-332. doi:10.1111/j.14682850.1998.tb00152.x

Deater-Deckard, K. (2005). Parenting stress and children's development: Introduction to the special issue. Infant and Child Development, 14(2), 111-115. doi:10.1002/icd.383

Feinberg, M. E. (2002). Coparenting and the transition to parenthood: A framework for prevention. Clinical Child and Family Psychological Review, 5(3), 173-195.

Gresham, F. M., \& Elliott, S. N. (1990). Social skills rating system: Manual. Circles Pines, MN: American Guidance Service.

Gülseven, Z., Carlo, G., Streit, C., Kumru, A., Selçuk, B., \& Sayıl, M. (2017). Longitudinal relations among parenting daily hassles, child rearing, and prosocial and aggressive behaviors in Turkish children. Social Development, 27(1), 45-57. doi:10.1111/sode.12247

Hu, L., \& Bentler, P. M. (1999). Cutoff criteria for fit indexes in covariance structure analysis: Conventional criteria versus new alternatives. Structural Equation Modeling: A Multidisciplinary Journal, 6(1), 1-55. doi:10.1080/10705519909540118

Huth-Bocks, A. C., \& Hughes, H. M. (2008). Parenting stress, parenting behavior, and children's adjustment in families experiencing intimate partner violence. Journal of Family Violence, 23(4), 243-251. doi:10.1007/s10896-007-9148-1

Katz, L. F., \& Low, S. M. (2004). Marital violence, co-parenting, and familylevel processes in relation to children's adjustment. Journal of Family Psychology, 18(2), 372-382. doi:10.1037/0893-3200.18.2.372

Koeske, G. F., \& Koeske, R. D. (1990). The buffering effect of social support on parental stress. American Journal of Orthopsychiatry, 60(3), 440-451. doi:10.1037/h0079164

Kokko, K., Tremblay, R. E., Lacourse, E., Nagin, D. S., \& Vitaro, F. (2006). Trajectories of prosocial behavior and physical aggression in middle childhood: Links to adolescent school dropout and physical violence. Journal of Research on Adolescence, 16(3), 403-428. doi:10.1111/j.15327795.2006.00500.x

Liu, L., \& Wang, M. (2015a). Parenting stress and children's problem behavior in China: The mediating role of parental psychological aggression. Journal of Family Psychology, 29(1), 20-28. doi:10.1037/fam0000047

Liu, L., \& Wang, M. (2015b). Parenting stress and harsh discipline in China: The moderating roles of marital satisfaction and parent gender. Child Abuse \& Neglect, 43, 73-82. doi:10.1016/j.chiabu.2015.01.014

Margolin, G., Gordis, E. B., \& John, R. S. (2001). Coparenting: A link between marital conflict and parenting in two-parent families. Journal of Family Psychology, 15(1), 3-21. doi:10.1037/08933200.15.1.3

McBride, B. A., Schoppe, S. J., \& Rane, T. R. (2002). Child characteristics, parenting stress, and parental involvement: Fathers versus mothers. Journal of Marriage and Family, 
64(4), 998-1011. doi:10.1111/j.1741-3737.2002.00998.x

McHale, J. P. (1997). Overt and covert coparenting processes in the family. Family Process, 36(2), 183-201. doi:10.1111/ j.1545-5300.1997.00183.x

McHale, J. P., Rao, N., \& Krasnow, A. D. (2000). Constructing family climates: Chinese mothers' reports of their coparenting behaviour and preschoolers' adaptation. International Journal of Behavioral Development, 24(1), 111118. doi:10.1080/016502500383548

Owen, A. E., Thompson, M. P., \& Kaslow, N. J. (2006). The mediating role of parenting stress in the relation between intimate partner violence and child adjustment. Journal of Family Psychology, 20(3), 505-513. doi:10.1037/08933200.20.3.505

Piff, P. K., Kraus, M. W., Côté, S., Cheng, B. H., \& Keltner, D. (2010). Having less, giving more: The influence of social class on prosocial behavior. Journal of Personality and Social Psychology, 99(5), 771-784. doi:10.1037/a0020092

Pinderhughes, E. E., Dodge, K. A., Bates, J. E., Pettit, G. S., \& Zelli, A. (2000). Discipline responses: Influences of parents' socioeconomic status, ethnicity, beliefs about parenting, stress, and cognitive-emotional processes. Journal of Family Psychology, 14(3), 380-400. doi:10.1037/0893-3200.14.3.380

Preacher, K. J., \& Hayes, A. F. (2008). Asymptotic and resampling strategies for assessing and comparing indirect effects in multiple mediator models. Behavior Research Methods, 40(3), 879-891. doi:10.3758/BRM.40.3.879

Richardson, E. W., Futris, T. G., Mallette, J. K., \& Campbell, A. (2018). Foster mothers' parenting stress and coparenting quality: An examination of the moderating role of support. Children and Youth Services Review, 89, 77-82. doi:10.1016/ j.childyouth.2018.04.024

Schermelleh-Engel, K., Moosbrugger, H., \& Müller, H. (2003). Evaluating the fit of structural equation models: Tests of significance and descriptive goodness-of-fit measures. Method of Psychological Research, 8(2), 23-74.

Schoppe, S. J., Mangelsdorf, S. C., \& Frosch, C. A. (2001). Coparenting, family process, and family structure: Implications for preschoolers' externalizing behavior problems. Journal of Family Psychology, 15(3), 526-545. doi:10.1037/08933200.15.3.526

Scrimgeour, M. B., Blandon, A. Y., Stifter, C. A., \& Buss, K. A. (2013). Cooperative coparenting moderates the association between parenting practices and children's prosocial behavior. Journal of Family Psychology, 27(3), 506-511. doi:10.1037/ a0032893

Song, J.-H., \& Volling, B. L. (2015). Coparenting and children's temperament predict firstborns' cooperation in the care of an infant sibling. Journal of Family Psychology, 29(1), 130135. doi: $10.1037 /$ fam 0000052
Teubert, D., \& Pinquart, M. (2010). The association between coparenting and child adjustment: A meta-analysis. Parenting: Science and Practice, 10(4), 286-307. doi:10.108 0/15295192.2010.492040

\section{In Korean}

Jang, H. E., \& Kim, C. K. (2017). The mediating effects of mother's emotional intelligence and empathy ability between parenting stress and children's prosocial behavior. Journal of Emotional \& Behavioral Disorders, 33(2), 65-81.

Jang, Y. A., \& Lee, Y. J. (2012). Effects of maternal behaviors, parenting stresses, and marital conflicts on children's aggression. Korean Journal of Family Therapy, 20(3), 357-373.

Jeon, E. (2015). The structural relationship among marital conflict, rearing stress and children's aggression and latent mean analysis of children's temperament. Early Childhood Education \& Care, 10(4), 97-119. doi:10.16978/ecec.2015.10.4.005

Kim, D. Y., \& Jung, K. (2015). The effect of maternal parenting stress on their children's pro-social behavior-Focused on the moderating effect of marital intimacy. Social Science Research Review, 31(4), 267-295.

Kim, K. H., \& Kang, H. (1997). Development of the parenting stress scale. Family and Environment Research, 35(5), 141-150.

Oh, K. J., \& Kim, Y. A. (2009). CBCL 1.5-5 revised manual. Seoul: Hunocunsulting.

Park, H. E., \& Park, J. H. (2017). The effects of child maltreatment from parents on reactive aggression among upper-elementaryschool students and the moderating role of effortful control. Korean Journal of Child Studies, 38(5), 5-17. doi:10.5723/ kjcs.2017.38.5.5

Ryou, K.-R. (2012). The relations of mother's parenting stress, parenting behavior, and parenting efficacy to children's social competence. The Journal of Child Education, 21(3), 231-240.

Seo, M.-O. (2004). A validation of the Korean version of the social skill rating system for preschool level (K-SSRS: Teacher and parent forms). Journal of Early Childhood Education, 24(2), 223-242.

\section{ORCID}

Youngsook Han Ths://orcid.org/0000-0001-8974-3684

Received February 1, 2019

Revision received March 23, 2019

Accepted April 5, 2019 